\title{
Effects of quinoline-arylamidine hybrids on LPS-induced inflammation in RAW 264.7 cells
}

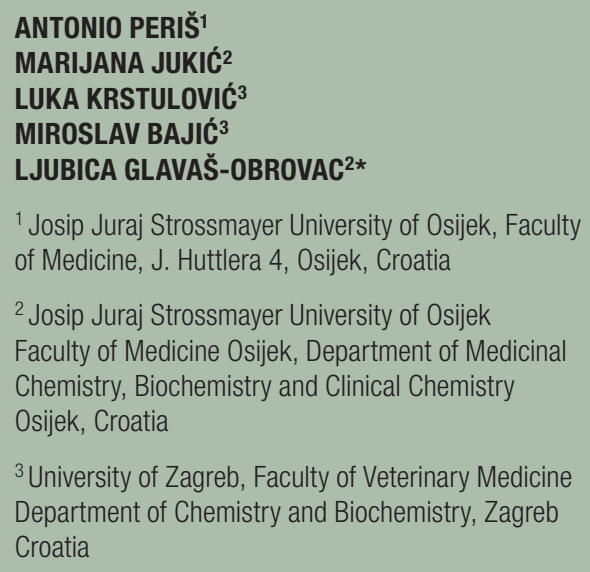

\section{*Correspondence:}

Ljubica Glavaš-Obrovac

E-mail address: Igobrovac@mefos.hr

Keywords: Hybrid molecules, 7-Chloroquinoline, Aromatic amidine, Anti-inflammatory activity in vitro
Received June 8, 2020

Revised July 12, 2020

Accepted July 13, 2020

\begin{abstract}
Background and purpose: Inflammation is a common pathogenesis in infection, injury, cancer, and many chronic diseases. Macrophages are among the main cells involved in generation of inflammation. The aim of the present study was to investigate the effects of molecular hybrids with 7-chloroquinoline and arylamidine moieties joined through flexible a 2-aminoethanol linker, on the in vitro inflammatory responses to lipopolysaccharides (LPS) induced inflammation in the RAW 264.7 cells.
\end{abstract}

Materials and methods: To determine effects of seven quinoline-arylamidine hybrids on the growth of the murine macrophage-like (RAW 264.7) cells MTT assay was used. Inflammatory reactions in the RAW264.7 cells were induced using E. coli lipopolysaccharides (LPS). Levels of nitric oxide (NO) and malondialdehyde (MDA) were determined by spectrophotometry methods. Intracellular production of reactive oxygen species (ROS) was measured by flow cytometry. Antioxidant capacity of tested compounds was tested by 2,2'-azino-bis(3-ethybenzthiazoline-6-sulfonic acid (ABTS) radical cation method.

Results: Tested hybrid compounds differentially influenced proliferation of non-stimulated and LPS-stimulated RAW 264.7 cells. The hybrid compounds have not presented ABTS radical-scavenger activity. In the LPSstimulated RAW 264.7 cells $10 \mu \mathrm{M}$ compounds slightly decreased production of NO and ROS and significantly modulated LPS-induced lipid peroxidation.

Conclusions: Molecular hybrids with 7-chloroquinoline and arylamidine moieties joined through flexible 2-aminoethanol linker markedly decreased accumulation of lipid peroxidation products in the LPS-stimulated RAW 264.7 cells. Further studies are necessary to determine their mechanism of anti-inflammatory action in more details.

\section{INTRODUCTION}

Inflammation is a common pathophysiological process in infection, injury, cancer, and many chronic diseases including autoimmune diseases, diabetes, Alzheimer's disease, cardiovascular and inflammatory bowel diseases (1). Although in the last two decades anti-inflammatory therapy in chronic diseases triggered by inflammation, deregulation or autoimmunity has significantly improved, there are considerable limitations while treatment choices of inflammatory process often express side effects or/and lack of effectiveness. For that reason, there is a continuing need to develop potent and less harmful anti-inflammatory drugs (2). 


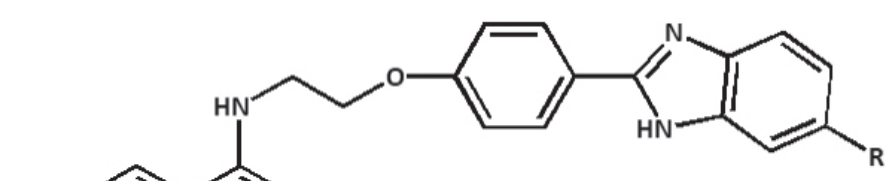

$\times 3 \mathrm{HCl}$

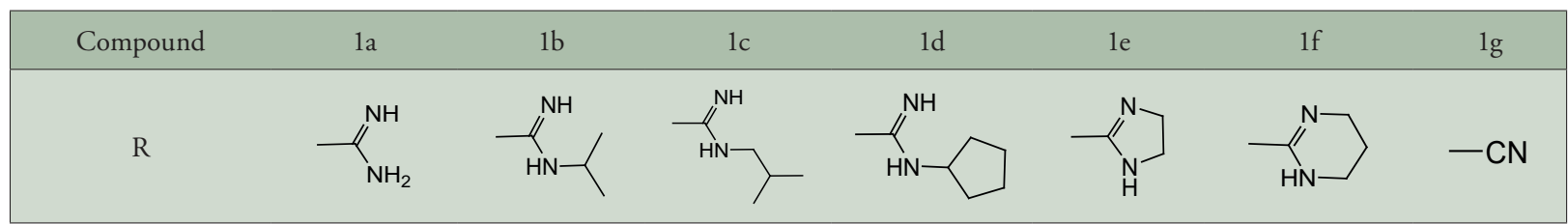

Figure 1. Structures of quinoline-arylamidine hybrids.

Nitrogen-containing heterocyclic molecules are obligatory structural units in medicinal chemistry with diverse applications. Among them, quinoline and its derivatives have attracted considerable attention due to their various pharmacological activities including antitumor, antioxidant, antiproliferative (3), and anti-inflammatory activity $(4,5,6)$. Having in mind that new drug development strategies are focusing on molecules that act simultaneously on multiple targets, either by a combination of at least two drugs or by combining two (or more) active pharmacophores in the single-hybrid molecule that has dual activity $(7,8)$, we recently reported on the synthesis and antitumor activity of four series of new molecular hybrids containing 7-chloroquinoline and arylamidine moieties joined through the rigid -O- or flexible - NH$\mathrm{CH}_{2}-\mathrm{CH}_{2}$-O- linker (9).

We found that the new hybrid molecules with 7-chloroquinoline displayed selectivity on carcinoma and leukemia cells, showing higher efficacy against leukemia cells (10).

Since the causal relationship between inflammation, innate immunity and cancer is more widely accepted and cancer-related inflammation has been proposed to promote tumor progression and serve as the seventh hallmark of tumor, we decided to expand our investigation to test anti-inflammatory potential of selected hybrid compounds.

Macrophages are the cornerstone of the innate immune system, which activation plays a significant role in homeostasis of organisms (11). In vitro macrophage activation techniques provide us with a window to understand the mechanisms of inflammation and response of macrophages to the modulating interventions (12). Nitric oxide (NO) is an important pro-inflammatory mediator produced by inducible nitric oxide synthase (iNOS) during conversion of l-arginine to l-citrulline. The reaction of $\mathrm{NO}$ with superoxide anion will form a strong cytotoxic oxidant, peroxynitrite, which increases the production of PGs and causes lipid peroxidation and cellular damage
(13). Pro-inflammatory cytokines are produced in large quantities by activated macrophages/monocytes that stimulate cellular responses via increasing prostaglandins (PGs) and reactive oxygen species (ROS). Additionally, lipid peroxidation (malondialdehyde, MDA) is produced by free radicals attacking the cell membranes. Thus, inflammatory effect results in the accumulation of MDA.

The aim of the present study was to investigate in vitro anti-inflammatory potential of molecular hybrids with 7-chloroquinoline and arylamidine moieties joined through flexible 2-aminoethanol linker. The anti-inflammatory activities of selected hybrids were evaluated by means of inhibiting reactive oxygen species (ROS) and nitric oxide (NO) production as well as MDA accumulation in the lipopolysaccharides (LPS) induced RAW 264.7 cells.

\section{MATERIAL AND METHODS}

\section{Compounds}

The synthesis, physical properties, and antitumor activity of new molecular hybrids with 7-chloroquinoline and arylamidine moieties joined through flexible 2-aminoethanol linker have been described previously (9). Structural details of all studied molecules are shown in Figure 1.

\section{Cell proliferation assay}

Effects of tested compounds on the murine macrophage-like cell line RAW264.7 (ATCC ${ }^{\circ}$ TIB-71) viability were determined using the colorimetric methyltetrazolium (MTT) assay. Briefly, RAW264.7 cells were cultured in RPMI 1640 medium supplemented with 10\% FBS, $2 \mathrm{mM}$ glutamine, $10 \mathrm{mM}$ sodium pyruvate and 2 $\mathrm{mM}$ HEPES. The cells were grown in tissue culture flasks (BD Falcon, Germany) in the humidified atmosphere under the conditions of $37^{\circ} \mathrm{C} / 5 \%$ of $\mathrm{CO}_{2}$ gas in the $\mathrm{CO}_{2}$ incubator (IGO 150 CELLlife $^{\mathrm{TM}}$, JOUAN, Thermo Fisher Scientific, Waltham, MA, USA). The cells were seeded 
in 96 micro-well plates at a concentration of $2 \times 10^{4}$ cells/ $\mathrm{cm}^{3}$ and treated with hybrid compounds $1 \mathrm{a}-1 \mathrm{~g}$ at a concentration range $100-0.1 \mu \mathrm{M}$ for $72 \mathrm{~h}$. Additionally, cells were pretreated with $10 \mu \mathrm{M} \mathrm{1a}-1 \mathrm{~g}$ or Trolox, as a reference compound, for $2 \mathrm{~h}$ and then stimulated with LPS $(1 \mu \mathrm{g} / \mathrm{mL})$ for $24 \mathrm{~h}$. After 24 and $72 \mathrm{~h}$ of incubation, medium was removed and $5 \mathrm{mg} / \mathrm{cm}^{3}$ MTT solution (Merck, New Jersey, SAD) was added to each well and incubated for $4 \mathrm{~h}$ in the $\mathrm{CO}_{2}$ incubator. Then, to each well, DMSO was added to dissolve water-insoluble MTT-formazane crystals. The Elisa microplate reader (iMark, BIO RAD, Hercules, CA, USA) was used for measurement of the absorbance at $595 \mathrm{~nm}$. All experiments were performed at least three times in triplicates. The percentage of cell growth $(\mathrm{PG})$ was calculated using the following equation:

$\mathrm{PG}=\left(\mathrm{A}_{\text {compound }}-\mathrm{A}_{\text {background }} / \mathrm{A}_{\text {control }}-\mathrm{A}_{\text {background }}\right) \times$ 100 , where $A_{\text {background }}$ at the adherent cells is the absorbance of MTT solution and DMSO; and $\mathrm{A}_{\text {control }}$ is the absorbance of cell suspension grown without tested compounds.

For the purpose of calculating $\mathrm{IC}_{50}$ values, cells were treated for $72 \mathrm{~h}$ with compounds at concentrations of 1 , 10,50 and $100 \mu \mathrm{M}$. Briefly, individual concentration effect curves ware generated by plotting the logarithm of the concentration of tested compounds.

\section{Total antioxidant capacity assay}

Total antioxidant capacity of the compounds $\mathbf{1 a}-\mathbf{1 g}$ was measured according to the method described previously on the basis of cell quenching capacity toward the 2,2'-azino-bis(3-ethybenzthiazoline-6-sulfonic acid (ABTS) radical cation (14). $\mathrm{ABTS}^{+}$was produced by the reaction between $7 \mathrm{mM}$ water solution of ABTS (SigmaAldrich, St. Louis, MO, USA) and $2.45 \mathrm{mM}$ ammonium persulfate (Sigma-Aldrich, St. Louis, MO, USA) (1:1), stored in the dark at room temperature for $12-16 \mathrm{~h}$ before the use. The $\mathrm{ABTS}^{+}$solution was then diluted with methanol to obtain an absorbance of 0.700 at $750 \mathrm{~nm}$. Adapted $\mathrm{ABTS}^{+}$solution was mixed with $50 \mu \mathrm{M}$ compounds (1:1). Esculetin and Trolox were used as standard compounds and were applied with the same concentration. Absorbance (A) was measured after 30 or 60 minutes of incubation in the dark at a room temperature after the initial mixing. An appropriate solvent blank was run in each assay. All the measurements were carried out at least three times. Percentage of inhibition of absorbance at 750 $\mathrm{nm}$ was calculated using the formula, $\mathrm{ABTS}^{+}$scavenging effect $(\%)=100-\left(\left(A_{s} / A_{b}\right) \times 100\right)$ where, $A_{b}$ was absorbance of ABTS radical + methanol, while $A_{s}$ was absorbance of ABTS radical + tested hybrids/standard.

\section{Measurement of intracellular ROS by flow cytometry}

The intracellular ROS produced by non-stimulated (control) and LPS-stimulated macrophages was detected by the Fluorometric Intracellular ROS Kit (Sigma-Aldrich, St. Louis, MO, USA) according to manufacturer's instructions. RAW264.7 cells $\left(5 \times 10^{5}\right.$ cells $\left./ \mathrm{cm}^{3}\right)$ were plated in 24-well plates and left over night in $\mathrm{CO}_{2}$ incubator. The non-stimulated RAW264.7 cells $\left(5 \times 10^{5}\right.$ per well in a 24-well plate) were incubated for $2 \mathrm{~h}$ with $10 \mu \mathrm{M}$ hybrid compounds or Trolox. Stimulated cells were preincubated with $10 \mu \mathrm{M}$ compounds for $2 \mathrm{~h}$ and then continuously stimulated with $1 \mu \mathrm{g} / \mathrm{mL}$ LPS (Lipopolysaccharides from Escherichia coli O111:B4; Sigma-Aldrich, St. Louis, MO, USA) for $24 \mathrm{~h}$. After the treatment cells were labeled with $1 \mu \mathrm{L}$ of $500 \mathrm{x}$ ROS detection reagent stock solution in $1 \mathrm{~mL}$ of cells suspension for $30 \mathrm{~min}$ at $37^{\circ} \mathrm{C}$ in a humidified atmosphere at $5 \% \mathrm{CO}_{2}$. The fluorescence intensity was measured by flow cytometry (FacsCanto II, BD Biosciences, USA) and analyzed using FlowJo software (Inivai Technologies, USA).

\section{Measurement of nitrite concentration}

Nitrite production as an indicator of nitric oxide (NO) intracellular levels was measured in the supernatant of the RAW264.7 macrophages (15). Cells $\left(5 \times 10^{5} \mathrm{cells} / \mathrm{cm}^{3}\right)$ were plated in 24-well plates and left over night in the $\mathrm{CO}_{2}$ incubator. Stimulated cells were pre-incubated with $10 \mu \mathrm{M}$ compounds for $2 \mathrm{~h}$ and then continuously stimulated with $1 \mu \mathrm{g} / \mathrm{mL}$ LPS (Sigma-Aldrich, St. Louis, MO, USA) for $24 \mathrm{~h}$. Cell's supernatant was collected and mixed in 1:1 ratio with Griess reagent (1\% sulphanilamide in 5\% phosphoric acid, and $0.1 \%$ naphthylethylenediamide, Sigma-Aldrich, St. Louis, MO, USA) dissolved in water. The mixture was then incubated at room temperature for $15 \mathrm{~min}$ in darkness. After 15-min incubation, the absorbance was read with an ELISA microplate reader (iMark, BIO RAD, Hercules, CA, USA). The nitrite concentrations were calculated from a sodium nitrite standard curve, and the NO concentrations in the supernatant were determined by comparison with the standard curve.

\section{Assessment of lipid peroxidation}

Lipid peroxidation was assayed by the measurement of the malondialdehyde (MDA) level by the thiobarbituric acid reacting substance (TBARS) method (16). RAW264.7 cells $\left(5 \times 10^{5}\right.$ cell $/ \mathrm{mL}$ ) were plated in 24 - $\mathrm{mi}-$ crowell plates and left over night in the $\mathrm{CO}_{2}$ incubator. Then, cells were treated with $10 \mu \mathrm{M}$ compounds or with Trolox for $2 \mathrm{~h}$ and then continuously stimulated with 1 $\mu \mathrm{g} / \mathrm{mL}$ LPS (Sigma-Aldrich, St. Louis, MO, USA) for 24 h. The culture supernatant was collected and mixed in ratio 1:2 with $30 \%$ trichloroacetic acid (Kemika, Zagreb, Croatia) and centrifuged $10 \mathrm{~min}$ on $3,500 \mathrm{~g}$. After centrifugation supernatant was mixed with TBA (2-thiobarbituric acid, Sigma-Aldrich, St. Louis, MO, USA) solution in a ratio $1: 1$ and then boiled at $95^{\circ} \mathrm{C}$ for $30 \mathrm{~min}$. The absorbance was measured at $532 \mathrm{~nm}$ using a UV/VIS spectrometer (Lambda 25 UV/VIS, PerkinElmer, USA). 
1,1,3,3- Tetraethoxypropane (Sigma-Aldrich, St. Louis, MO, USA) serial dilution standard curve were performed and TBARS values were expressed as $\mu \mathrm{M}$ of malondialdehyde (MDA) equivalents.

\section{Statistical analysis}

All described experiments were done in triplicate. A nonparametric Mann-Whitney test was applied to analysis antiproliferative effects. Statistical difference between all data groups in an experiment were compared using one-way analysis of variance (ANOVA) pair wise comparison with Dunnett (two sided) analysis. All analyses were done with 95\% confidence interval $(\alpha=0.05)$.

\section{RESULTS AND DISCUSSION}

In this study we examined effects of molecular hybrids with 7-chloroquinoline and arylamidine moieties joined through flexible - $\mathrm{NH}-\mathrm{CH}_{2}-\mathrm{CH}_{2}-\mathrm{O}$ - linker on induction of oxidative stress and inflammation in the lipopolysaccharides (LPS) stimulated RAW 264.7 cells. To determine optimal concentrations of hybrid compounds for further experiments, antiproliferative effects of $\mathbf{1 a - 1 g}$ were assessed in the non-stimulated RAW 264.7 cells after $72 \mathrm{~h}$ of treatment.

As shown in the Figure 2, hybrid compounds 1a-1e in 0.1 to $10 \mu \mathrm{M}$ range of concentration were not cytotoxic. Only $10 \mu \mathrm{M}$ compound $\mathbf{1 g}$ significantly influenced the growth of the RAW 264.7 cells. Statistically significant decreases in cell survival were observed when hybrid compounds $1 \mathbf{a}-\mathbf{1} \mathbf{g}$ were applied at highest tested concentration of $100 \mu \mathrm{M}$. The calculated $\mathrm{IC}_{50}$ values $(\mu \mathrm{M})$ were for $\mathbf{1 a}$ : 49.6 \pm 7.2 ; for $1 \mathbf{b}$ : $39.1 \pm 6.6$; for 1 c: $57.5 \pm 2.5$; for $1 \mathbf{d}: 45.4 \pm 8.0$ for 1e: $34.3 \pm 1.9$; for $\mathbf{1 f}: 75.4 \pm 2.3$ and for $\mathbf{1 g}: 1.6 \pm 0.8$.
Furthermore, the effects of $10 \mu \mathrm{M}$ hybrid compounds 1a-1g and Trolox, as a reference compound, on LPSstimulated RAW 264.7 cells' growth were also tested. As shown in Figure 3, lipopolysaccharides from E. coli (LPS) applied in concentration of $1 \mu \mathrm{g} / \mathrm{mL}$ during $24 \mathrm{~h}$ had no cytotoxic effect on the growth of RAW 264.7 cells. After $24 \mathrm{~h}$ of incubation, Trolox and hybrid compounds $\mathbf{1 b}, \mathbf{1 d}$, 1e, and $\mathbf{1 f}$ did not show significant effects on the LPSstimulated cells' growth. Weak antiproliferative effects were shown by the $\mathbf{1 a}$ and $\mathbf{1 c}$, while $\mathbf{1 g}$ completely inhibited the LPS-stimulated cells (Figure 3). Based on described results, we excluded the molecular hybrid $\mathbf{1 g}$ and selected the $10 \mu \mathrm{M}$ concentration of hybrid compounds 1a-1f as the optimal concentration for the subsequent experiments.

It is well known that normal cellular metabolic process involving mitochondrial respiratory chain produces ROS while excessive ROS production results in mitochondrial dysfunction which is strongly associated with other pathological conditions, including inflammation (17). Macrophages in vivo and in vitro upon stimulation by LPS exhibit inflammatory responses by excessive accumulation of nitric oxide and superoxide anion whose interaction result in different pathophysiological conditions (11). By analyzing antioxidant capacity of the new synthesized hybrids $\mathbf{1 a - 1 f}$ we wanted to determine if there is a correlation between radical scavenging capacity of tested compounds, redox status in the LPS-stimulated RAW 264.7 cells and their responsiveness to tested compounds.

In our experimental conditions, $\mathbf{1 a - 1 f}$ did not induce changes in ROS levels in the non-stimulated RAW 264.7 cells (data not shown). As shown in the Figure 4, intracellular levels of ROS in the RAW cells stimulated by LPS for $24 \mathrm{~h}$ increased almost two times compared

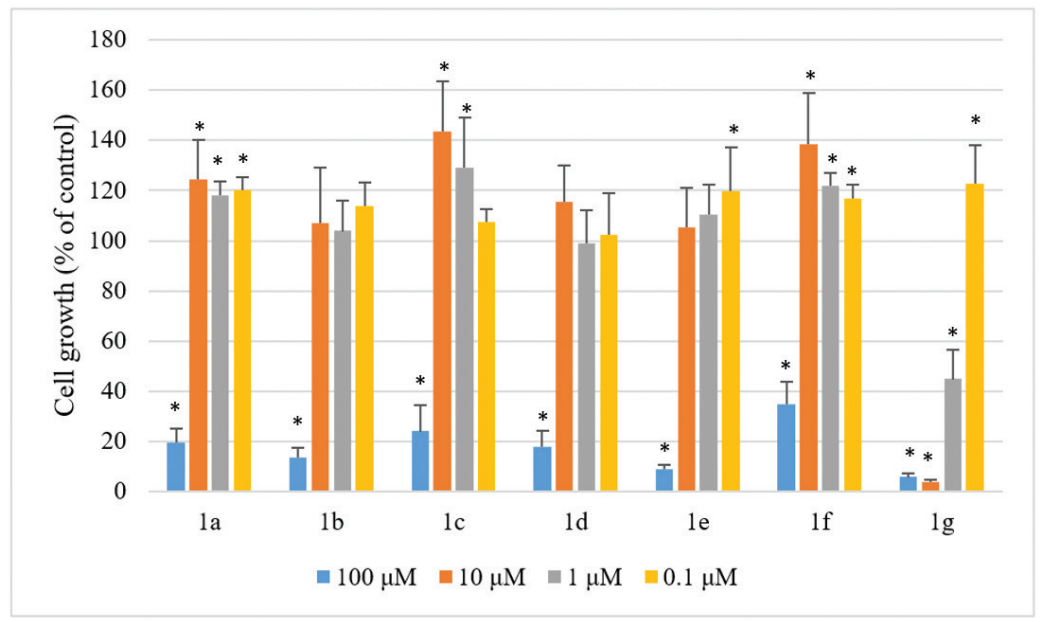

Figure 2. Inhibitory effects of molecular quinoline-arylamidine hybrids 1a-1g on the growth of the RAW 264.7 cells. Cytotoxicity was analyzed after $72 \mathrm{~h}$ of incubation using the MTT survival assay. The percentage of treated cells growth inhibition was calculated relative to the growth of untreated (control) cells. Data are presented as the mean value \pm SD of three independent experiments done in triplicates. 


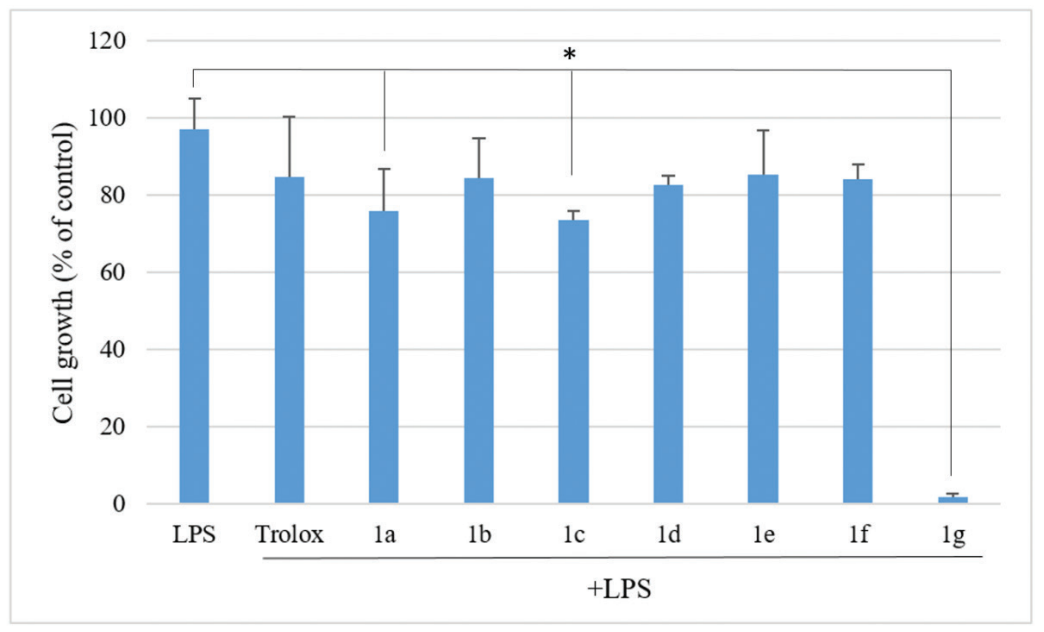

Figure 3. Cytotoxic effects of $10 \mu \mathrm{M}$ quinoline-arylamidine hybrids $1 \mathrm{a}-1 \mathrm{~g}$ and Trolox on the RAW 264.7 cells' growth after pretreatment for $\mathbf{2} \mathbf{h}$ and stimulation with $\mathbf{1 \mu g} / \mathbf{m L}$ LPS for $\mathbf{2 4} \mathbf{h}$. LPS: control cells stimulated by lipopolysaccharides (LPS) for $24 \mathrm{~h}$. Cytotoxicity was analysed using the MTT survival assay. The percentage of treated cells growth inhibition was calculated relative to the growth of untreated (control) cells. Data are presented as the mean value $\pm S D$ of three independent experiments done in triplicates

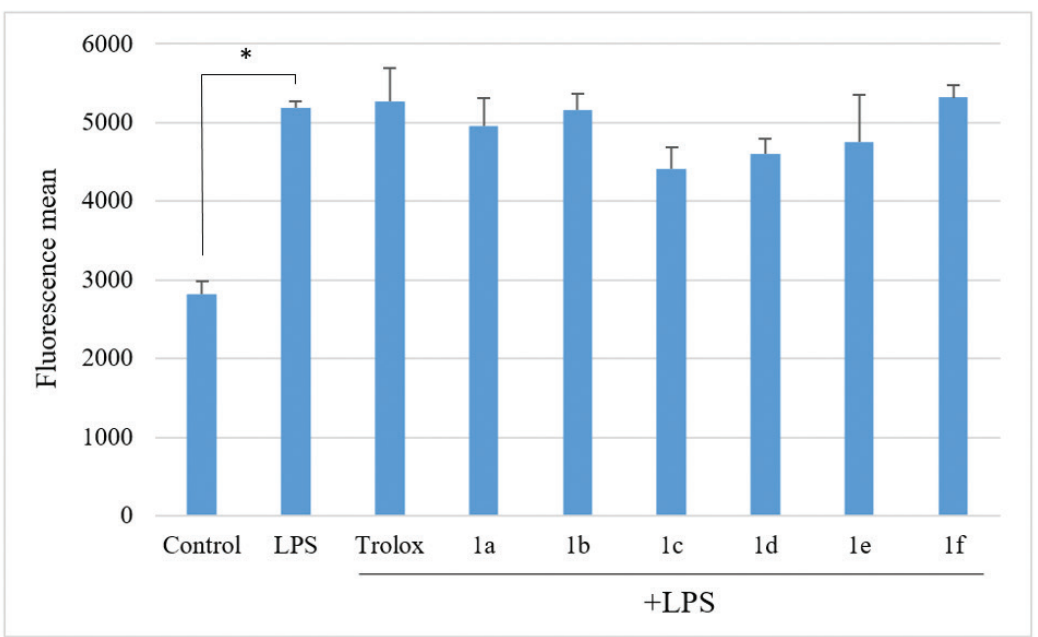

Figure 4. Effect of hybrid compounds 1a-1f on the RAW264.7 intracellular ROS accumulation. Cells $\left(5 \times 10^{5}\right.$ per well in a $96-$ well plate) were pre-incubated with $10 \mu \mathrm{M}$ hybrids for $2 \mathrm{~h}$ and then continuously stimulated with $1 \mu \mathrm{g} / \mathrm{mL}$ LPS for $24 \mathrm{~h}$. Control: non-treated and non-stimulated cells. LPS: cells stimulated by LPS for $24 \mathrm{~h}$. Data are given as mean fluorescence of ROS level with \pm SD. One-way ANOVA with Dunnett analysis $(\alpha<0.05)$ were used to examined differences between control cells and by bybrids treated cells.

to non-stimulated (control) cells. In LPS-activated RAW 264.7 cells we recorded a slight decrease in the ROS accumulation after treatment with all tested compounds (Figure 4).
Since free-radical scavenging is one of the well-known mechanisms by which many compounds act as antioxidants we evaluated in vitro antioxidant capacity of tested compounds by 2,2'-azino-bis(3-ethybenzthiazoline-

Table 1. Radical scavenging capacity (RSC) of tested hybrid compounds $\mathbf{1 a - 1} \mathbf{f}^{*}$

\begin{tabular}{|ccccccccc|}
\hline Compound & $1 \mathrm{a}$ & $1 \mathrm{~b}$ & $1 \mathrm{c}$ & $1 \mathrm{~d}$ & $1 \mathrm{l}$ & $1 \mathrm{f}$ & Trolox & Esculetin \\
\hline RSC (\%) & $14.0 \pm 2.2$ & $0.2 \pm 0.1$ & $3.7 \pm 0.3$ & $0.2 \pm 0.1$ & $0.6 \pm 0.1$ & $1.4 \pm 0.2$ & $91.5 \pm 2.0$ & $91.4 \pm 1.5$ \\
\hline
\end{tabular}

*2,2-Azinobis-3-ethylbenzothiazoline-6-sulfonic acid cation $\left(\mathrm{ABTS}^{+}\right)$scavenging effect expressed as mean ( $\mathrm{n}=3$ ) values \pm SD after 60 minutes of incubation. 
6-sulfonic acid (ABTS) radical cation method. Obtained results showed that in vitro scavenger activity of tested hybrids $\mathbf{1 a}-\mathbf{1 f}$ is negligible ( 0.2 to 14.2 respectively) compared to reference compounds, Trolox and Esculetin (Table 1).

As nitric oxide (NO) is an important pro-inflammatory mediator produced by inducible nitric oxide synthase in macrophages $(5,12)$, we examined whether or not tested hybrid compounds 1a-1f could reduce the LPSinduced generation of NO in the RAW 264.7 cells. Obtained results showed that LPS stimulation led to statistically significant increase in NO production (to 169.2 \pm 9.4 $\mu \mathrm{M})$ in LPS stimulated cells compared to the non-treated and non-stimulated control cells $(26.7 \pm 2.4 \mu \mathrm{M})$. We found that $10 \mu \mathrm{M}$ hybrid compounds $\mathbf{1 a}, \mathbf{1 b}$, and $\mathbf{1 e}$ significantly reduced production of NO in LPS-activated macrophages by about $20-25 \%$ compared to LPS induced control cells, indicating their potential as a NOscavenging compounds. In the applied concentration
Trolox had no effect on the NO production in LPS stimulated cells compared to LPS control cells (Figure 5a).

Nitrosative and/or oxidative stress-induced lipid peroxidation is detrimental because it alters the biological properties of the cellular membrane, such as degree of fluidity and inactivated membrane-bound receptors and enzymes, which impairs normal cellular function and increases tissue permeability (18). Therefore, lipid peroxidation products such as malonylaldehyde (MDA) are often used as markers of oxidative/nitrosative damage (19). Thiobarbitoric acid (TBA) assay is the most commonly used method for determination of the MDA in biological fluids. As shown in Figure 5b, LPS stimulation of the RAW 264.7 cells increased TBARS production for more than double in the LPS stimulated cells compared to the non-stimulated control cells. The $2 \mathrm{~h}$ pretreatment with $10 \mu \mathrm{M}$ hybrid compounds $\mathbf{1 a - 1 d}$ caused statistically significant decrease in the MDA accumulation in the LPS-stimulated RAW 264.7 cells compared to control cells and completely restored the TBARS content to con-
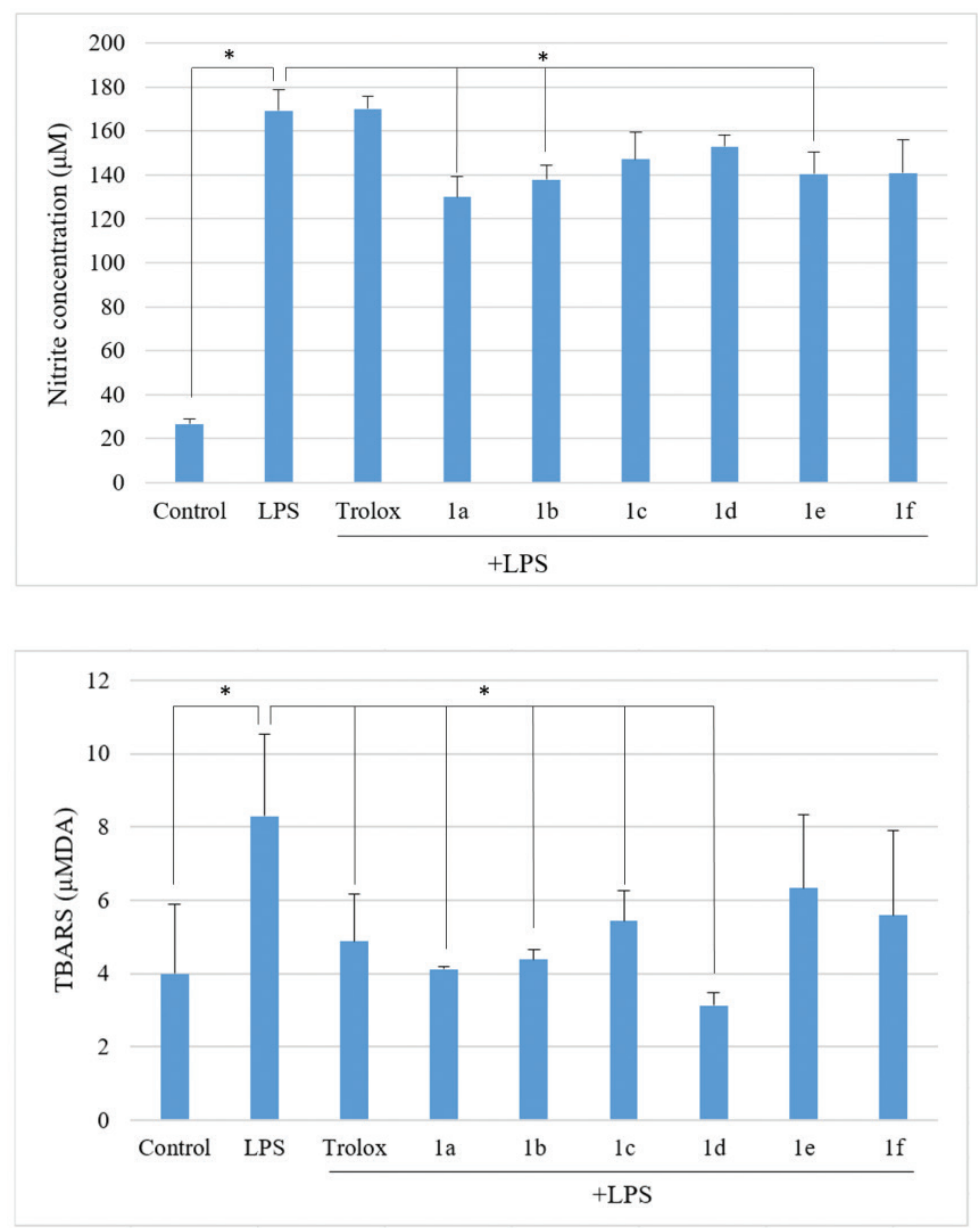

Figure 5. Effect of hybrid compounds on NO production (a) and TBARS generation (b) in LPS stimulated RAW264.7 cells. Cells $\left(5 \times 10^{5}\right.$ per well in a 96-well plate) were pre-incubated with $10 \mu \mathrm{M}$ hybrids for $2 \mathrm{~h}$ and then continuously stimulated with $1 \mu \mathrm{g} / \mathrm{mL}$ LPS for $24 \mathrm{~h}$. Control: non-treated and non-stimulated cells. LPS: cells stimulated by LPS for $24 \mathrm{~h}$. Results are expressed as mean values with $\pm S D$. One-way ANOVA with Dunnett analysis $(\alpha<0.05)$ were used to examine differences between LPS stimulated cells and compound-treated cells. 
trol levels. Obtained results are in line with findings that bifunctional hybrids containing 7-chloroquinoline have a very good potential to demonstrate significant anti-inflammatory activity $(4,20,21)$.

\section{CONCLUSIONS}

The results presented in this study demonstrate that molecular hybrids with 7-chloroquinoline and arylamidine moieties joined through flexible 2-aminoethanol linker slightly modulated the production of $\mathrm{NO}$ and $\mathrm{ROS}$ and did not present significant ABTS radical-scavenger activity. At the same time, our results suggest a pharmacological potential of this class of compounds since a markedly decreased accumulation of lipid peroxidation products in the LPS-stimulated RAW 264.7 cells was noticed. Further studies are necessary to investigate mechanisms of action of these compounds. Compounds from this series will serve as a template for the future design of new analogues with improved antitumor and anti-inflammatory activities.

Acknowledgements: The authors gratefully acknowledge financial support from the Faculty of Medicine, University of Osijek supporting grant to Lj. Glavaš-Obrovac (VIF2018-MEFOS-6).

Declaration: The authors declare no competing interests.

\section{REFERENCES}

1. CHEN L, DENG H, CUI H, FANG J, ZUO Z, DENG J, LI Y, WANG X, ZHAO L 2018 Inflammatory responses and inflammation-associated diseases in organs. Oncotarget (6): 7204-7218. https://doi.org/10.18632/oncotarget.23208

2. WEN X, WANG S., LIU D, GONG D, QUAN Z 2015 Synthesis and evaluation of the anti-inflammatory activity of quinoline derivatives. Med Chem Res 24: 2591-2603

https://doi.org/10.1007/s00044-015-1323-y

3. FREITAS LB, BORGATITF, DE FREITAS RP, RIUZ AL; MARCHETTI GM, DE CARVALHO JE, DA CUNHA EFF, RAMALHO TC, Alves RB 2014 Synthesis and antiproliferative activity of 8-hydroxyquinoline derivatives containing a 1,2,3-triazole moiety. Eur J Med Chem 84: 595-604.

https://doi.org/10.1016/j.ejmech.2014.07.061

4. GUPTA SK, MISHRA A 2016 Synthesis, characterization \& screening for anti-inflammatory $\&$ analgesic activity of quinoline derivatives bearing azetidinones scaffolds. Antiinflamm Antiallergy Agents Med Chem 15(1): 31-43.

https://doi.org/10.2174/1871523015666160210124545

5. TSENG CH, TUNG CW, PENG SI, CHEN YL TZENG CC, CHENG CM 2018 Discovery of pyrazolo[4,3-c]quinolines derivatives as potential anti-inflammatory agents through inhibiting of NO production. Molecules 23(5): 1036. https://doi.org/10.3390/molecules23051036

6. YANG CY, HUNG YL, TANG KW, WANG SC, TSENG CH, TZENG CC, LIU PL, LI CY, CHEN YL 2019 Discovery of 2-substituted 3-arylquinoline derivatives as potential anti-inflammatory agents through inhibition of LPS-induced inflammatory responses in macrophages. Molecules 24(6): 1162.

https://doi.org/10.3390/molecules24061162

7. ANIGHORO A, BAJORATH J, RASTELLI G 2014 Polypharmacology: Challenges and opportunities in drug discovery. J Med Chem 57: 7874-7887. https://doi.org/10.1021/jm5006463

8. FORTIN S, BERUBE G 2013 Advances in the development of hybrid anticancer drugs. Expert Opin Drug Discov 8: 1029-1047. https://doi.org/10.1517/17460441.2013.798296

9. KRSTULOVIĆ L, STOLIĆ I, JUKIĆ M, OPAČAK-BERNARDI T, STARČEVIĆ K, BAJIĆ M, GLAVAŠ-OBROVAC L 2017 New quinoline-arylamidine hybrids : Synthesis, DNA/RNA binding and antitumor activity. Eur J Med Chem 137:196-210.

http://dx.doi.org/10.1016/j.ejmech.2017.05.054

10. RASTIJA V,JUKIĆM, OPAČAK-BERNARDIT, KRSTULOVIĆ L, STOLIĆ I, GLAVAŠ-OBROVAC L, BAJIĆ M 2019 Investigation of the structural and physicochemical requirements of quinoline- arylamidine hybrids for the growth inhibition of K562 and Raji leukemia cells. Turkish J Chem 43: 251-265.

https://doi.org/10.3906/kim-1807-61

11. WYNN TA, CHAWLA A, POLLARD JW 2013 Macrophage biology in development, homeostasis and disease. Nature 496(7446): 445-455. https://doi.org/10.1038/nature12034

12. PARADKAR PH, MISHRA LS, JOSHI JV, DANDEKAR SP, VAIDYA RA, VAIDYA AB 2017 In vitro macrophage activation: A technique for screening anti-inflammatory, immunomodulatory and anticancer activity. Indian J Exp Biol 55: 133-141.

13. LIAO JC, TSAI JC, PENG WH, CHIU YJ, SUNG PJ, TSUZOKI M, KUO YH 2013 Anti-inflammatory activity of N-(3-florophenyl) ethylcaffe amide in mice. Int J Mol Sci 14: 15199-15211. https://doi.org/10.3390/ijms140815199

14. EREL O 2004 A novel automated direct measurement method for total antioxidant capacity using a new generation, more stable ABTS radical cation. Clin Biochem 37: 277-285.

https://doi.org/10.1016/j.clinbiochem.2003.11.015

15. MOSHAGE H, KOK B, HUIZENGA JR, JANSEN PL 1995 Nitrite and nitrate determinations in plasma: A critical evaluation. Clin Chem 41: 892-896.

16. TATUM VL, CHANCHIT CC, CHOW K 1990 Measurement of malondialdehyde by high performance liquid chromatography with fluorescence detection. Lipids 25: 226-229.

17. KRUK J, ABOUL-ENEIN HY, KLADNA A, BOWSER JE 2019 Oxidative stress in biological systems and its relation with pathophysiological functions: the effect of physical activity on cellular redox homeostasis. Free Radical Research 53: 497-521. https://doi.org/10.1080/10715762.2019.1612059

18. KURUTAS EB 2015 The importance of antioxidants which play the role in cellular response against oxidative/nitrosative stress: current state. Nutr J 15: 71.

https://doi.org/10.1186/s12937-016-0186-5

19. HUNG YL, FANG SH, WANG SC, CHENG WC, LIU PL, SU CC, CHEN CS, HUANG MY, HUA KF, SHEN KH, WANG YT, SUZUKI K, LI CY 2017 Corylin protects LPS-induced sepsis and attenuates LPS-induced inflammatory response. Sci Rep 7: 46299. https://doi.org/10.1038/srep46299

20. MUKHERJEE S, PAL M 2013 Medicinal chemistry of quinolines as emerging anti-inflammatory agents: an overview. Curr Med Chem 20(35): 4386-4410. https://doi.org/10.2174/09298673113209990170

21. SARAIVAMT, KRÜGER R, BALDINOTTI RSM, LENARDÃO EJ, LUCHESE C, SAVEGNAGO L, WILHELM EA, ALVES D 2016 7-Chloroquinoline-1,2,3-triazoyl carboxylates: Organocatalytic synthesis and antioxidant properties. J Braz Chem. Soc 27(1): 41-53. http://dx.doi.org/10.5935/0103-5053.20150239 